\title{
The Effect of Problem Based Learning (PBL) Learning Models on Mathematic Problem Solving Ability Students in Primary School
}

\author{
Agus Kistian $^{1}$, Verawati ${ }^{2}$ \\ ${ }^{1,2}$ STKIP Bina Bangsa Meulaboh, Indonesia \\ aguskistian92@gmail.com
}

\begin{abstract}
This study aims to determine the effect of the Problem Based Learning (PBL) learning model on the mathematics problem solving ability of students in $4^{\text {th }}$ grade primary school Pasi Pinang. This research uses a quantitative approach, with the type of research is quasi experimental. The population in this study were all fourth grade students of primary school Pasi Pinang and the sampling technique in this study was selected by total sampling of two classes. The experimental class was treated with the Problem Based Learning (PBL) learning model and the control class was treated with the expository learning model. The instruments used consisted of a learning motivation questionnaire and a math problem solving ability test. Data analysis was carried out using two-way ANOVA. From the results of this study, it was obtained that the average result of the mathematics problem solving ability taught by the Problem Based Learning (PBL) learning model was 82.16 while the average result of the mathematics problem solving ability taught by the expository learning model was 71. , 36. So it can be concluded that the results of the mathematics problem solving ability of students who are taught with the Problem Based Learning (PBL) learning model are higher than students who are taught with the Expository learning model.
\end{abstract}

Keywords

ProblemBased Learning (PE); learning motivation; mathematical problem solving ability

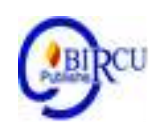

\section{Introduction}

In the process of teaching and learning activities, it is necessary to have a learning model whose emphasis is on the ability to solve problems in mathematics learning. Mathematical problem solving skills can help students make the right decisions based on careful, systematic, logical efforts, and consider various points of view, especially in mathematics.

Mathematics is one component of a series of subjects that have an important role in education (Sundayana, 2015: 2). The following shows the objectives of learning mathematics based on Permendiknas No. 22 of 2006, namely: (1) understanding mathematical concepts, explaining the relationship between concepts, and applying concepts or algorithms, in a flexible, accurate, efficient, and precise way to solve problems; (2) using reasoning on patterns and properties, performing mathematical manipulations in making generalizations, compiling evidence, or explaining mathematical ideas and statements; (3) solving problems which include the ability to understand problems, design mathematical models, solve models, and interpret the solutions obtained; (4) communicating ideas with symbols, tables, diagrams, or other media to clarify the situation or problem; (5) having an attitude of appreciating the usefulness of mathematics in life, namely having curiosity, attention, and interest in learning mathematics, as well as being resilient and confident in problem solving. Based on the five goals that have been stated, this means that mathematics is needed by everyone in everyday life to help solve problems. 
Based on the results of observations made in $4^{\text {th }}$ grade primary school Pasi Pinang, it was found that students tended to be less active and less motivated to learn, and often tasks were completed at school by seeing the results of their friends 'work that had been completed, the students' mathematical problem solving abilities had not yet reached class completion. . The average percentage of KKM attainment is $63 \%$. This makes the students 'mathematical problem solving abilities not developed and most of the students' mathematical problem solving abilities in mathematics are still below the specified minimum completeness criteria (KKM), namely 65.

Based on the values and explanations above, the factors that cause students' low mathematical problem solving abilities are the lack of use of appropriate learning approaches or models in order to provide students with maximum mathematical problem solving abilities and the learning model used by the teacher has not been able to develop abilities. problem solving students learn mathematics. Therefore, there is a need for an improvement in the process or variation in mathematics learning to help students develop mathematical problem solving skills and increase student motivation in learning mathematics. The learning model that is considered appropriate to assist students in developing students' mathematical problem solving abilities and motivation to learn mathematics is the Problem Based Learning (PBL) learning model.

One of the learning models that can activate and fulfill the various learning needs of students is the PBL learning model. Problem Based Learning is a learning model that teaches students to develop thinking skills and problem-solving skills, as well as to train students' independence (Bound \& Felleti in Husnidar et al, 2014). The PBL learning model is an influential way of learning in which students use authentic problems as a context for in-depth investigation of what they need and what they need to know. PBL is different from didactic teaching to students, faced with a description of a new situation or event, are required to define their learning needs and questions in order to achieve understanding of the situation or event.

The application of the PBL model is intended to determine the ability to develop thinking skills, problem-solving abilities, to train independence, learning motivation, and learning outcomes of students. In this lesson students learn how to use concepts and interaction processes to assess what they know, students can foster problem-solving skills to solve problems in mathematics learning, act as problem solvers and in learning think processes, group work, communicate and mutually provide motivation.

According to Polya in Yulianti, Sukasno, \& Friansah (2016) problem solving ability is an effort to find a way out of a difficulty in order to achieve a goal that is not so easy to achieve immediately. Therefore, problem solving is an effort to find a way out of a difficulty in order to achieve a goal that is not easily achieved by drawing on the knowledge that is owned through action, step by step systematically which will build a new mathematical understanding.

Based on the description above, the researcher can conclude that the PBL learning model is an appropriate model to be applied to mathematics learning. Because the PBL learning model is able to provide learning conditions that can develop students' thinking skills, creativity and problem-solving abilities so that student learning outcomes can increase. This is an alternative that researchers use to improve the quality of mathematics learning. 


\section{Review of Literature}

\subsection{Learning Model Problem Based Learning (PBL)}

The PBL model aims to cultivate critical thinking students to solve a problem and be able to find alternative solutions to problems. Through the PBL Model, students can be directly involved in solving problems and finding solutions that will be needed in real life. Sutirman (2013: 39) states that "Problem-based learning is a learning process that uses a systematic approach to solve problems or face challenges that will be needed in real life". Furthermore, according to Fathurrohman (2015: 112) the PBL model is;

"Learning that uses real (authentic) unstructured (ill-structured) problems which are open as a context for students to develop problem solving skills and critical thinking as well as build new knowledge".

PBL-based learning process (Imelda, 2019) are namely: (1) orienting the students toward the problems; (2) organizing the students to learn; (3) guiding the students to perform investigations both individually and collectively; (4) developing and presenting the problemsolving procedure; and analyzing and evaluating the problem-solving process

Furthermore, Rusman (2014: 241) says that the PBL Model is one of the learning models used to stimulate students' high-level thinking in real-world problem-oriented situations, including learning how to learn.

Based on the opinions of the experts above, it can be concluded that PBL is a learning model that uses a systematic approach to solve real-world problems (authentic) so that students can think critically while building new knowledge including learning how to learn.

\subsection{PBL Model Steps}

Basically the PBL model encourages students to be able to think critically in solving a problem. There are steps for implementing the PBL model that must be considered so that the learning objectives are in accordance with the objectives to be achieved. Furthermore, according to Sutirman (2013: 41) the steps for implementing problem-based learning are:

1) Students are given problems by the teacher based on student experiences;

2) Students hold discussions in small groups to:

a. Clarify a given case or problem.

b. Identify the problem.

c. Exchange opinions based on the experience they have.

d. Define the things that are needed to solve the problem.

e. Define what to do to solve the problem.

3) Students conduct independent studies related to problems that must be resolved;

4) Students return to the original problem-based learning group to exchange information, peer learning, and cooperate in solving problems;

5) Students are assisted by the teacher to evaluate all learning activities;

According to Al-Thabany (2014: 72) there are five main steps in implementing the PBL model, namely:

1) Orient students to the problem;

2) Organizing students to learn;

3) Guiding investigating independently or in groups;

4) Combining and presenting works; and

5) Analyze and evaluate the results of problem solving.

Based on the opinions of several experts above, the researcher chose the opinion of AlThabany who argued that there were five stages in the PBL learning steps including: 
1) Orient students to the problem;

2) Organizing students to learn;

3) Guiding investigating independently or in groups;

4) Combine and present the work; and

5) Analyze and evaluate the results of problem solving.

\subsection{The Nature of Mathematical Problem Solving Ability}

Good learning must be problem-based learning that is close to student life. Permendiknas No. 22 of 2006 explains that "problem solving is a focus in learning mathematics which includes closed problems with a single solution, open problems with nonsingle solutions, and problems with various ways of solving". Problem solving ability is an effort that a person makes in solving the problem he is facing, and can create new ideas to achieve the expected goals. Ruseffendi (2006) states that problem-solving abilities are very important in mathematics, not only for those who will study mathematics in the future, but also for those who will apply it in other fields of study and in everyday life.

Problem solving requires a strategy to solve it. Truth, accuracy, tenacity and speed are things that are needed in solving problems. Students' skills in developing a strategy are an ability that must be seen by the teacher. The correct answer is not an absolute standard measure, but a more important process from which students can get the answer. There are a variety of strategies that are expected to appear in elementary school student learning. There are various ways students can solve these problems. As stated by Suwangsih and Tiurlina (2010: 25), there are several mathematical problem solving strategies used to solve problems, including the following:

a) Reaction (Act It Out)

b) Making a picture or diagram.

c) Find a pattern.

d)Create a table.

e)Pay attention to all possibilities systematically.

f) Guess and check.

g)Work backward strategy.

h)Determining what is known, asked for, and the information required.

i) Using open sentences.

j) Change the point of view.

k)The strategies described can be selected to be used as a way of finding answers to existing problems. This strategy can make students more creative thinking in solving existing problems and will be able to develop their representational power and problem-solving abilities.

Problem solving functions in mathematics learning according to the National Council of Teachers Mathematics (2000), include:

a) Problem solving is an important tool in studying mathematics. Many mathematical concepts can be introduced effectively to students through problem solving.

b) Problem solving can equip students with knowledge and tools so that students can formulate, approach and solve problems according to what they have learned in school.

The ability to solve mathematical problems according to BSNP (2006) includes the ability to understand problems, design mathematical models, solve models, and interpret the solutions obtained. To measure mathematical problem solving ability, several indicators are needed. Indicators of problem solving according to Sumarmo (2012) are as follows:

1) identify the elements that are known, asked for, and the adequacy of the elements;

2) create a mathematical model; 
3) implementing strategies to solve problems in / outside mathematics;

4) explain or interpret the results;

5) solve mathematical models and real problems;

6) Use mathematics meaningfully.

Based on the description above, in this study the problem solving indicators used are two problem solving indicators according to Sumarmo (2012) including (1) identifying the elements that are known, asked, and the adequacy of elements; and (2) creating a mathematical model.

\subsection{Relevant Research}

Some of the previous studies related to the application of the Problem Based Learning learning model include:

1) Based on the results of research conducted by Riswari, et al entitled "The Effect of Problem Based Learning by using Demonstration Method on The Ability of Problem Solving", it is concluded that the successful application of the Problem Based Learning learning model can improve the mathematics problem solving abilities of school students. Basic Kajeksan.

2) In addition, the next relevant research is based on the results of research conducted by Hidayat, et al with the title "Analysis of Problem-Solving Abilities of Elementary School Students Through Problem-Based Learning Model Based on Self Confidence", concluded that he obtained the results of the research. shows that there is an increase in mathematical problem-solving abilities and student self-confidence very satisfactorily (successfully),

Based on the results of the study, the researchers drew the following conclusions: Students 'mathematical problem solving abilities that were applied using the PBL learning model were higher than the mathematical problem solving abilities using the direct learning model as measured by the students' mathematical problem solving abilities by answering the questions given in the comparison material. .

Based on the collection of relevant research results above, it can be concluded that the learning process using the PBL learning model can improve students' mathematical problem solving abilities. In the PBL learning model, the knowledge obtained by students is not only from the teacher, but students acquire their own knowledge in the learning process, so that the learning process that takes place can develop students' mathematical problem solving abilities.

\section{Research Method}

This research was conducted in $4^{\text {th }}$ grade primary school Pasi Pinang, West Aceh Regency. In this study, the population was $4^{\text {th }}$ grade primary school Pasi Pinang, namely 2 classes consisting of 50 students, where $4^{\text {th }}$ grade--A were 25 students and $4^{\text {th }}$ grade--B were 25 students. To determine the sample class, the sampling technique used is the total sampling technique. The sample class used was 2 classes totaling 50 students, $4^{\text {th }}$ grade--A as many as 25 students as PBL class and $4^{\text {th }}$ grade-B with 25 students as expository class. The research method used is Quasi Experimental Quasi (Quasi Experimental Method). The design of this study can be presented with a 2 x 1 factorial design with 1-way analysis of variance (ANAVA) techniques. In order to achieve the stated research objectives, it is necessary to develop a systematic procedure. The steps taken are the preparation stage, implementation stage, and reporting stage. To obtain data in this study, two kinds of instruments were used, namely tests and questionnaires. The test is used to determine students' mathematical problem 
solving abilities and a questionnaire to measure student learning motivation. The data analysis technique used is descriptive and inferential statistical techniques. To test the research hypothesis, data analysis techniques were used using one-way Analysis of Variance (ANOVA) at the significance level $\alpha=0.05$. Using the univariate General Linear Model (GLM) test with SPSS 20 for windows. If the results of the analysis of variance indicate an interaction (interaction effect) on the independent variable in relation to the dependent variable, the analysis is continued with the Tuckey test for the same sample and the Schefe test for different numbers of samples.

\section{Result and Discussion}

\subsection{Description of Research Data}

The results obtained in this study included the test scores of students' mathematical problem solving abilities in classes taught using the PBL learning model and using the expository learning model in mathematics learning in class IV SDN Pasi Pinang.

\section{a. Students' Mathematical Problem Solving Ability with PBL Learning Model}

After the learning is completed, students are given post-test mathematics questions both in PBL and expository classes. Post-test questions that have indicators of mathematical problem-solving abilities in the form of essays totaling 10 questions. Posttest of mathematics problem solving abilities was given for two hours of learning. This looks at whether there is an increase or improvement after students are taught PBL and Expository. Data on mathematical problem solving abilities provided by the PBL learning model, the average score was 82.16. The lowest score for students' mathematical problem solving abilities through the PBL learning model is 68 , while the highest score is 100 . For more details, it is explained in the following table:

Table 1. List of Frequency Distributions of Students' Mathematical Problem Solving Ability with the PBL Learning Model

\begin{tabular}{|c|c|c|}
\hline \multicolumn{3}{|c|}{ Classroom learning model Problem Based Learning (PBL) } \\
\hline Score & F & F relatively (\%) \\
\hline $68-73$ & 5 & 20 \\
\hline $74-79$ & 3 & 12 \\
\hline $80-85$ & 9 & 36 \\
\hline $86-91$ & 3 & 12 \\
\hline $92-97$ & 4 & 16 \\
\hline $98-100$ & 1 & 4 \\
\hline Total & $\mathbf{2 5}$ & $\mathbf{1 0 0}$ \\
\hline Mean & \multicolumn{2}{|c|}{} \\
\hline
\end{tabular}

\section{b. Data on Students' Mathematical Problem Solving Ability with Expository Learning} Model

Data on mathematical problem solving abilities provided by the expository learning model, the average score was 71.36. The lowest score for students' mathematical problem solving abilities through the expository learning model is 52 , while the highest score is 88 . For more details, it is explained in the following table: 
Table 2. List of Frequency Distribution of Students' Mathematical Problem Solving Ability with Expository Learning Model

\begin{tabular}{c|c|c|}
\hline \multicolumn{3}{|c|}{ The expository learning model class } \\
\hline Score & F & F relatively (\%) \\
\hline $52-57$ & 2 & 8 \\
\hline $58-63$ & 5 & 20 \\
\hline $64-69$ & 2 & 8 \\
\hline $70-75$ & 4 & 16 \\
\hline $76-81$ & 9 & 36 \\
\hline $82-88$ & 3 & 12 \\
\hline Total & $\mathbf{2 5}$ & $\mathbf{1 0 0}$ \\
\hline Mean & \multicolumn{2}{|c|}{$\mathbf{7 1 , 3 6}$} \\
\hline
\end{tabular}

\subsection{Analysis of Research Results}

\section{a. Data Analysis of Students' Mathematical Problem Solving Ability Tests}

The next research stage is the analysis of the results of the observations. The initial analysis carried out was the comparison of post-test data in the two sample classes. The data comparison is presented in Figure 4.1. If calculated the comparison of the average score of the students' mathematics problem solving ability in the class using the PBL learning model was 82.16, while in the class the use of the expository learning model was 71.36. From these data it can be concluded that the average score of the mathematics problem solving ability test of students who are taught by using the PBL learning model is better than the average score of the mathematics problem solving ability test using the expository learning model.

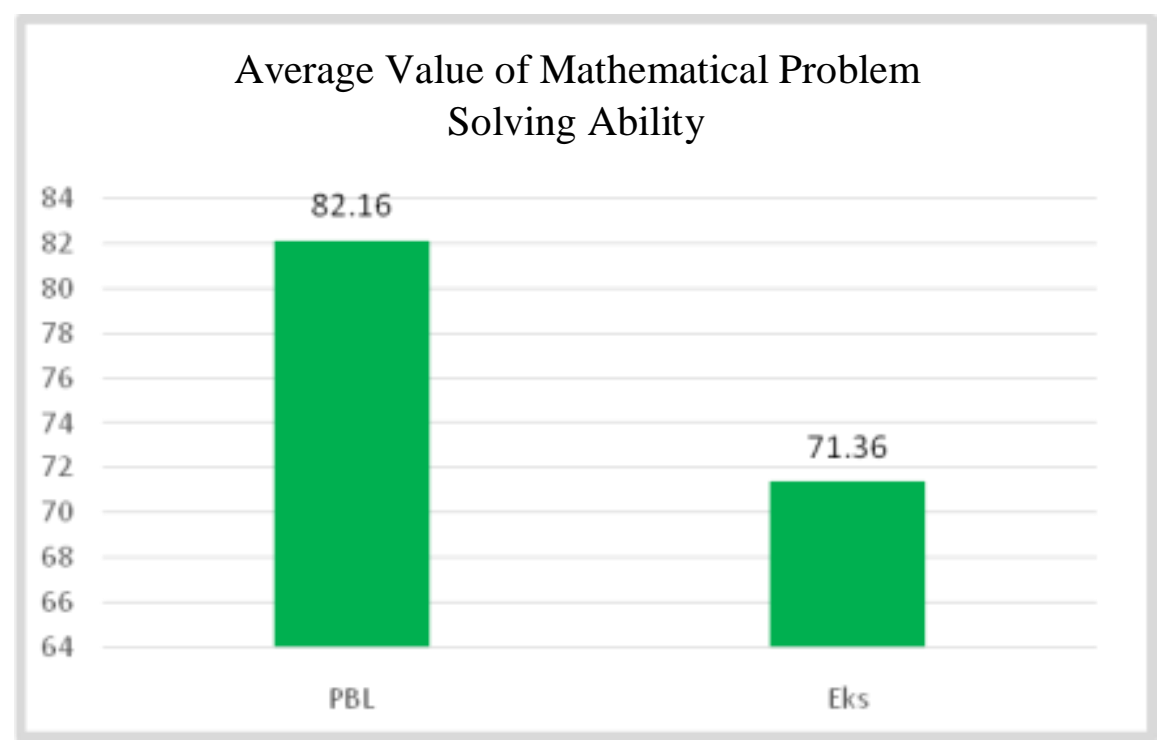

Figure 1. The Class Student's Mathematical Problem Solving Ability Test Using the PBL learning model and the Classroom Expository learning model

\section{b. Hypothesis test}

After the data has been collected and statistically analyzed, then the hypothesis is tested. This hypothesis test uses the one-way Anava test whose calculations are assisted by SPSS 16 for windows. From the data obtained from the problem solving ability test, the mean of each group was calculated and then compiled as a one-way ANOVA table. In summary, the data is presented in the following table. 
Table 3. Design Factorial Mean $2 x 1$

\begin{tabular}{c|c|}
\hline \multicolumn{2}{c|}{ Mean test results of math problem solving abilities } \\
\hline $\begin{array}{c}\text { Learning Model Problem Based } \\
\text { Learning (PBL) }\end{array}$ & $\begin{array}{c}\text { Expository learning } \\
\text { model }\end{array}$ \\
\hline 82,16 & 71,36 \\
\hline
\end{tabular}

To see students 'problem-solving abilities on the given learning, the One Way Anova Test was used by selecting the Univariate General Linear Model (GLM) at SPSS 16. This test also aims to see how the effect of the Problem Based Learning (PBL) learning model on students' problem solving abilities.

Furthermore, the data normality is tested on students' problem solving abilities. The results of the normality test are presented in table 3 . The normality value with Kolmogorov Smirnov is 0.072 with a significance of 0.219 . Because the significance value $(0.219)$ is greater than 0.05 , the data is normally distributed. The Q-Q graph plot of the normal distribution of the posttest data is shown in the following figure.

Table 4. Results of Normality Test of Students' Mathematical Problem Solving Ability Tests of Normality

\begin{tabular}{|c|c|c|c|c|c|c|}
\hline & \multicolumn{3}{|c|}{ Kolmogorov-Smirnov $^{\mathrm{a}}$} & \multicolumn{3}{|c|}{ Shapiro-Wilk } \\
\hline & Statistic & $\mathrm{df}$ & Sig. & Statistic & $\mathrm{df}$ & Sig. \\
\hline postes & .119 & 50 & .072 & .969 & 50 & .219 \\
\hline
\end{tabular}

a. Lilliefors Significance Correction

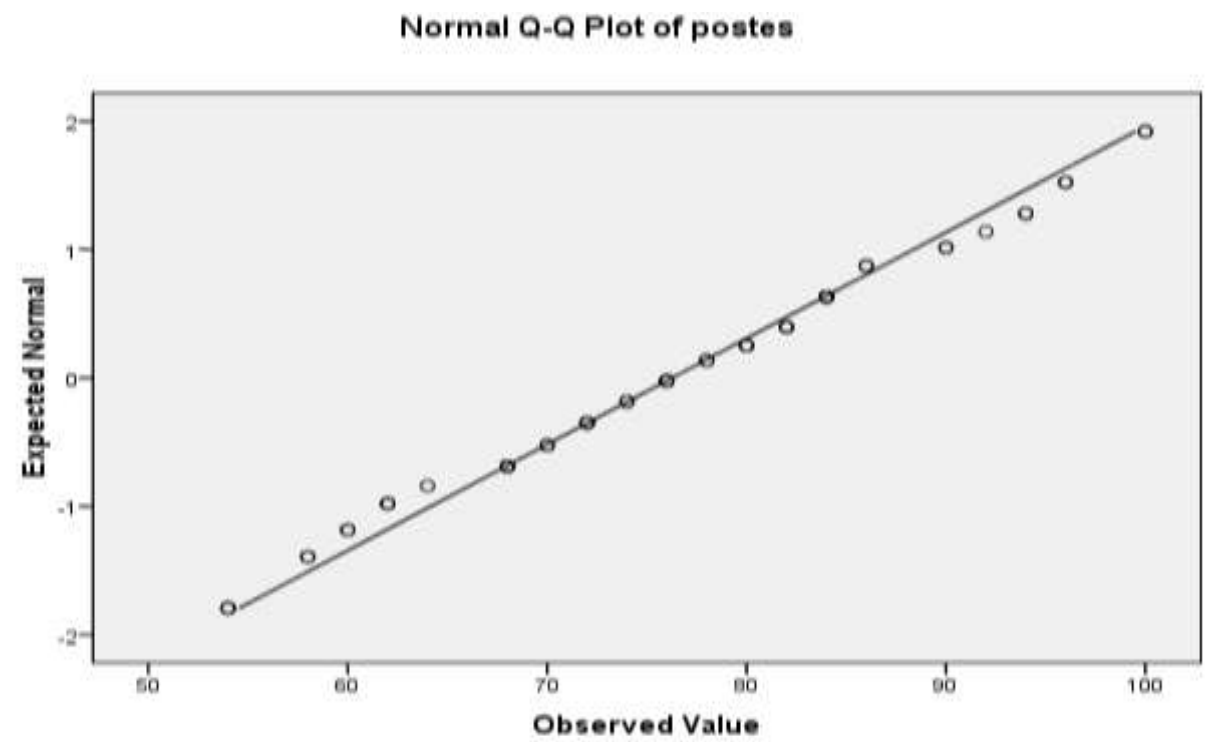

Figure 2. Q-Q Plot of Results of Students' Mathematical Problem Solving Ability Using the PBL learning model and the use of the expository learning model

Furthermore, the assumption test that must be fulfilled is the Homogeneity Test to see if there is a similarity in variance. The results of the homogeneity test are shown in table 5. The test results show that the $F$ value in the table is 1.403 with a significance of 0.242 because the sig value. $0.242>0.05$, the two groups are homogeneous 
Table 5. Homogeneity Test between Groups Test of Homogeneity of Variances

postes

\begin{tabular}{|c|c|c|c|}
\hline Levene Statistic & df1 & df2 & Sig. \\
\hline 1.403 & 1 & 48 & 242 \\
\hline
\end{tabular}

Furthermore, the results of the one-way ANOVA test are shown in the following table.

Table 6. One Way Anova Test Results

\section{Tests of Between-Subjects Effects}

Dependent Variable: Skills

Math Problem Solving

\begin{tabular}{|l|r|r|r|r|r|r|}
\hline \multicolumn{1}{|c|}{ Source } & \multicolumn{1}{c|}{$\begin{array}{c}\text { Type III Sum } \\
\text { of Squares }\end{array}$} & df & \multicolumn{1}{c|}{$\begin{array}{c}\text { Mean } \\
\text { Square }\end{array}$} & \multicolumn{1}{c|}{ F } & \multicolumn{1}{c|}{ Sig. } & \multicolumn{1}{c|}{$\begin{array}{c}\text { Partial Eta } \\
\text { Squared }\end{array}$} \\
\hline Corrected & 3086.607 & 3 & 1028.869 & 19.019 & .000 & .554 \\
Model & 292781.147 & 1 & 292781.147 & $5.412 \mathrm{E} 3$ & .000 & .992 \\
Intercept & 1534.821 & 1 & 1534.821 & 28.371 & .000 & .381 \\
Class & 2488.513 & 46 & 54.098 & & & \\
Error & 300180.000 & 50 & & & & \\
Total & 5575.120 & 49 & & & & \\
Corrected & & & & & \\
Total & & & & & \\
\hline
\end{tabular}

a. R Squared $=, 554$ (Adjusted R Squared $=, 525$ )

The data in table 6 is used to test the hypotheses proposed in this study. The following is a description of the results of the hypothesis testing.

$\mathrm{H} 0: \mu \mathrm{A} 1=\mu \mathrm{A} 2$ : there is no effect of the PBL learning model on students' mathematical problem solving abilities

Ha: $\mu \mathrm{A} 1 \neq \mu \mathrm{A} 2$ : there is an effect of the PBL learning model on students' mathematical problem solving abilities

Based on the ANOVA results in table 6, the significance value of the learning model is 0.000 because sig. $0.000<0.05$, the hypothesis test results rejecting $\mathrm{H} 0$ or accepting $\mathrm{Ha}$ in the alpha level of 5\%. This shows that there is an effect of the Problem Based Learning (PBL) learning model on students' mathematical problem solving abilities. Because the average problem-solving ability of students who are taught with the Problem Based Learning (PBL) learning model is higher than those taught by Expository learning, it can be concluded that the PBL learning model has a better effect on students' problem-solving abilities than the Expository learning model.

\section{Conclusion}

Based on the results of the research obtained, several conclusions can be drawn as follows: There is an effect of the PBL learning model on the mathematics problem solving abilities of the fourth grade students of SDN Pasi Pinang. This can be seen from the results of students 'mathematical problem solving abilities taught with the PBL learning model better than the results of students' mathematical problem solving abilities taught with expository. 


\section{References}

Al-Tabany, Trianto Ibnu Badar. (2014). Mendesain Model Pembelajaran Inovasi, Progresif, dan Kontekstual. Prenadamedia Group: Jakarta.Fathurrohman.

Arikunto, S. (2013). Prosedur Penelitian Suatu Pendekatan Praktek. PT Rineka Cipta. Jakarta.

Badan Standar Nasional Pendidikan (BNSP). 2006. Panduan Penyususnan Tingakat Satuan Pendidikan Jenjang Pendidikan Dasar dan Menengah. Badan Standar Pendidikan. Jakarta.

Depdiknas. (2006). Permendiknas No 22 Tahun 2006 Tentang Standar Isi. Jakarta: Depdiknas.

Fathurrohman, M. (2015). Model-model Pembelajar an Inovatif. Ar-Ruzz Media. Yogyakarta.

Hidayat P.W, Susilowati E.M.S, Ellianawati. (2020). Analysis of Problem-Solving Abilities of Elementary School Students Through Problem-Based Learning Model Based on Self Confidence. Journal of Primary Education, 9 (1).

Husnidar, et al. (2014). "Penerapan Model Pembelajaran Berbasis Masalah Untuk Meningkatkan Kemampuan Berpikir Kritis Dan Disposisi Matematis Siswa”. Jurnal Didaktik Matematika, 1 (1): 71-82.

Imelda, et al. (2019). Students' Activities in Learning with Problem Based Learning Based Module to Enhance Students' HOTS on the Subject of Straight Line Equations. Budapest International Research and Critics in Linguistics and Education (BirLE) Journal. P. 552-559

NCTM. (2000). Principles and Standars for School Mathematics. Reston: National Council of Teachers of Mathematics, Inc.

Riswari A.L., Yanto H, Sunarso A. (2018). The Effect of Problem Based Learning by using Demonstration Methodon The Ability of Problem Solving. Journal of Primary Education, 7(3): 356-362.

Ruseffendi. (2006). Pengantar Kepada Membantu Guru Mengembangkan Kompetensinya dalam Pengajaran Matematika . Bandung: Tarsito.

Rusman. (2014). Model-Model Pembelajaran (Mengembangkan Profesionalisme Guru). PT. Raja Grafindo Persada: Jakarta.

Sumarmo, U., E, \& Rahmat. (2012). Suatu Alternatif Pengajaran Untuk Meningkatkan Pemecahan Masalah Matematika pada Guru dan Siswa SMA. Bandung: FPMIPA IKIP Bandung.

Sundayana, R. (2015). Media dan alat peraga dalam pembelajaran matematika. Bandung: Alfabeta.

Sutirman. (2013). Media dan Model-Model Pembelajaran Inovatif. Graha Ilmu: Yogyakarta

Suwangsih, E. \& Tiurlina. (2010). Model pembelajaran matematika.Bandung : UPI Press.

Yulianti, E., Sukasno, \& Friansah, D. (2016). Pengaruh Model Problem Based Learning (PBL) Terhadap Kemampuan Pemecahan Masalah Matematis Siswa Kelas X SMA Negeri 2 Lubuk Linggau. 